\title{
LYL1 Gene
}

National Cancer Institute

\section{Source}

National Cancer Institute. LYL1 Gene. NCI Thesaurus. Code C24564.

This gene plays a role in transcriptional regulation and is involved in the pathogenesis of acute lymphoblastic leukemia. 